\title{
Tracing the Provenance of Unfired Ancient Egyptian Clay Figurines from Saqqara through Non-Destructive X-Ray Fluorescence Spectrometry
}

D. Braekmans ${ }^{1,2,3,4}$, V. Boschloos ${ }^{5,6}$, H. Hameeuw ${ }^{5,6,7,8}$, and A. Van der Perre ${ }^{6,8}$

${ }^{1}$ Cranfield Forensic Institute, Cranfield University, Defence Academy of the United Kingdom, Shrivenham SN6 8LA, United Kingdom

${ }^{2}$ Delft University of Technology, Materials Science and Engineering, Mekelweg 2, 2628 CD Delft, The Netherlands

${ }^{3}$ Leiden University, Faculty of Archaeology, Laboratory for Ceramic Studies, Einsteinweg 2, 2333 CC Leiden, The Netherlands

${ }^{4}$ KU Leuven, Section Geology, Earth and Environmental Sciences, Celestijnenlaan 200E, 3001 Heverlee, Belgium

${ }^{5}$ Ghent University, Department of Archaeology, Sint-Pietersnieuwstraat 33-35, 9000 Ghent, Belgium

${ }^{6}$ Royal Museums of Art and History, Department of Antiquity, Jubelpark 10, 1000 Brussels, Belgium

${ }^{7}$ KU Leuven, ULS Digitisation and Document Delivery, Mgr. Ladeuzeplein 21, 3000 Leuven, Belgium

${ }^{8}$ KU Leuven, Research Unit Archaeology, Blijde-Inkomststraat 21, 3000 Leuven, Belgium

Corresponding author: D. Braekmans, email: dennis.braekmans@cranfield.ac.uk

\section{Abstract}

A collection of Prime Cultural Heritage artefacts consisting of Egyptian late Middle Kingdom figurines (c. 1850-1700 BCE), made of unfired clay and covered in inscriptions, is kept at the Royal Museums of Art and History (RMAH) in Brussels, Belgium. Several of these hieratic inscriptions curse enemies of the Egyptian state, including Canaanite, Nubian and Libyan entities; thus providing invaluable information for Middle Bronze topography in ancient Near Eastern studies. What makes the extensive Brussels group even more exceptional, is the fact that these figurines were discovered in a closed archaeological context in Saqqara, Lower Egypt. Defining and classifying clay and ancient ceramic provenance groups in Egypt is highly complex due to variability in Nile and marl clay deposits. Chemical characterization of this figurine assemblage ( $\mathrm{n}=91)$ allows to effectively study the potential direct use of clays in the vicinity of Saqqara and characterize the nature of the raw materials used. Additionally, it aims to assess the validity of portable XRF spectrometry for this type of materials and its provenance resolution. Analyses show that very similar clays were used to produce the different morphological types of figurines in the assemblage. The chemical profile indicates the use of a mixed source at Saqqara rather than pure marl or Nile clays, which are common for ancient pottery production.

Keywords: clay figurine characterization; unfired clay objects; non-destructive chemical analysis; ancient Egypt; Portable XRF; clay provenance 


\section{Introduction}

An exceptional collection of Egyptian late Middle Kingdom figurines (c. 1850-1700 BCE), made of unfired clay and covered in inscriptions, is housed at the Royal Museums of Art and History (RMAH) in Brussels (Fig. 1). The inscriptions express curses aimed at (potential) enemies of Egyptians or the Egyptian state as a whole, such as Levantine, Nubian or Libyan entities (Posener, 1940; Van der Perre et al., forthcoming). In general, such execration figurines are badly preserved because they were ritually broken, intentionally burned or buried, in order to symbolically neutralize the enemy and offer protection against dangerous forces (Ritner, 1993). The Brussels group of figurines was discovered in a closed archaeological context, namely a cenotaph near the Teti pyramid at Saqqara North, Lower Egypt (Fig. 2) (Posener, 1940; Abdalla, 1992).

Being crucial primary sources for our knowledge of ancient onomastica and the political geography of the ancient Near East and Egypt, they are regarded as Prime Cultural Heritage artefacts, but a significant part of the figurines is in a poor state, due to the fragility of the unfired clay. Therefore, urgent measures need to be taken to ensure their optimal further preservation, including a comprehensive analysis of the material and its surfaces. Facing the problem of a lack of reference frameworks for the study of unfired clay objects from Egypt (see below 2.), the present work offers the results of the initial analysis of the clay composition. As the clay is unfired, the objects have moreover the potential to directly correlate these materials with clay sources. Due to the nature of these objects, supposedly being disposable objects, it is generally assumed that local and easily accessible clay sources were used. Two research questions pertain to the material composition and require analytical techniques. Firstly, while the history of the discovery suggests that all figurines were discovered in a single place of origin, a characterization of the composition of the clay is required to determine whether the material confirms the use of a single clay source. The second research question concerns the homogeneity of the group. The Brussels figurines were divided in five groups based on a morphological typology and show potential for paleographical classification as well: their features are shaped differently and several handwritings can be distinguished in the inscriptions (Posener, 1939). It was therefore decided to determine whether the morphological typology subdivision is mirrored in the clay composition. 
Since the figurines are museum objects and extremely brittle, the use of (micro)destructive methods is not an option. Non-destructive and in situ analysis by portable X-Ray Fluorescence (pXRF) was preferred as the most suitable method to assess this relative visible homogeneity, based on an analysis of mid to heavy $\mathrm{Z}$ elements in clay and ceramics studies (Padilla et al. 2006; Degryse \& Braekmans 2014). As an additional concern, several conservation or consolidation treatments have been applied in the past but, unfortunately, these had been hardly documented (Van der Perre et al., forthcoming).

\section{Clay raw materials and Egyptian ceramic provenance studies}

In Egyptian archaeology, the raw clays used for ceramic production are generally divided into three groups: Nile silts, marl clays and kaolin clays. Both Nile silts and marl clays were used throughout the Pharaonic period in the entire Nile Valley, while kaolin clays were mainly used from the early Roman period onwards (Bourriau \& Nicholson 1992; Bourriau et al. 2000; Nordström \& Bourriau 1993). Nile silts, i.e. clays deposited by the river between the Upper Pleistocene and the present, are rich in silica and iron and appear grey to black in their raw state. Marl clays, originating from shales and limestone found along the river, are calcareous and rich in mineral salts (Bourriau et al., 2000). However, typical marl clays with good properties for pottery production are especially confined to the area around Qena, Upper Egypt (Arnold $\&$ Bourriau, 1993). These clay raw materials were used to create a wide variety of fabrics. They were often mixed, for example Nile silt mixed with carbonate grains or general carbonate/marl components. A non-site specific classification system, the so-called Vienna System, is generally used to identify the particular fabric type of ceramics (Arnold \& Bourriau, 1993).

The current challenge with ceramic provenancing, especially in Egypt, is related to the composition of the clay. On the one hand, most minor and trace elements are not distributed homogeneously in the clay beds. Secondly, clays were often selected from heterogeneous clay deposits (Rapp \& Hill, 2006). Another issue is that mainly fired pottery samples are used for provenance studies, while it can be complicated to connect these to local clay beds. Clays were often prepared before being used; impurities were removed, different clays were mixed, or a temper was added. Moreover, the effects of firing can influence the compositional nature of the 
materials (Kilikoglou et al., 1988). Finally, the (surface) composition pattern of the clay can be influenced by reactions during the burial of the analyzed objects and cause mobility of certain elements. For example, many Egyptian ceramics exhibit a so-called scum layer (Ownby \& Griffiths 2009). Whereas local characteristics and variations can often be detected by visual analysis, this generally cannot determine the exact place of production. Although provenancing clearly requires scientific analyses, these are still rarely applied in Egyptian pottery studies (Schiestl \& Seiler, 2012a). The available targeted geochemical provenance studies on Egyptian objects and clay mineral resources treat various areas and periods and highlight the difficulty in sourcing these materials (Spataro et al. 2018). An increasing amount of studies succeed in determining an exact provenance of a ceramic assemblage in Egypt, especially when analyzing the output of a local production center (Allen et al., 1989; Hamroush \& Zeid, 1990; Ballet \& Picon, 1990).

By analyzing unfired clay objects, the ultimate objective of this research is to provide additional information that allows to identify the use of mineral resources in the past and that contributes to the characterization of locally and regionally produced ceramic materials and clay beds. Since we are dealing with unfired clay objects, the main challenges - as opposed to ceramic studies are: 1) the lack of a significant reference framework compared to pottery studies and the latter less relevant due to changes that might occur during and after firing; and 2) the fragile state of unfired surfaces and, subsequently, their sensitivity to external influences and interventions (conservation and preservation). With this study, we therefore aim to evaluate if meaningful differences can be identified through non-destructive chemical analysis of the unfired objects, related to technology and, potentially, their provenance. Secondly, this study seeks to provide an assessment on the possibility to distinguish different sources of Nile clay and/or marl clay and to establish whether natural or intentional mixtures of clay were utilized for these particular unfired objects.

\section{The geological setting of Saqqara}

Geological investigations in the region of Saqqara have been the scope of several studies and described in detail (Said, 1975; 1990; Moustafa, 1988; Papa 2003; Youssef et al. 1984; Hamdan et al. 2018; Stanley \& Jonathan G. Wingerath 1996; Hamdan 2000; Hamdan et al. 2014). The 
site of Saqqara itself is locatedon a plateau consisting of mainly Upper Eocene limestone, marl and claystone. The Eocene Limestone (Mokattam Formation) substrate is bordered by Pleistocene sediments to the north and south, while more Eocene limestone (Maadi Formation) and Pliocene sediments can be found to the west. The floodplain Nile alluvial sediments are located to the east. The Saqqara-Abu Sir Plateau - exposing the Upper Eocene Saqqara Member and overlooking the Nile floodplain - consists of laminated alternating layers of light yellow, hard limestone and yellow marl with layers of marly to sandy limestones and shale at the top. Older strata include Upper Eocene marly shale deposits including several gypsum bands, overlain by calcareous layers of the Saqqara Member (Yehia, 1985). Also, the Late Pliocene Helwan Formation (Said, 1975; 1990) consists of fine-grained sandstone and shale. Apart from the Nile floodplain and the limestone plateau, a cuesta scarp is located at the eastern side of the plateau. Attested quaternary sediments in the immediate area contain mostly sand and gravel with thin layers of Nile silt (Hamdan et al. 2014; Hamdan 2000). Especially floodplain sediments can be influenced by variations in paleoclimatic and paleoenvironmental developments throughout the Holocene, more notably around the collapse of the Egyptian Old Kingdom (ca. 2100 BCE). Recently, however, geochemical data from floodplain deposits at Saqqara has become available for this specific Middle to New Kingdom period. These deposits range from sandy to clayey silt and are enriched in carbonate and manganese concretions (Hamdan et al. 2018).

\section{Material}

Preliminary research on the clay was conducted using a trinocular microscope Leica M80 with 8:1 zoom range and magnification of $7.5 x-60 x$, identifying the unfired clay as mainly Nile silt. In addition, selected fracture surfaces were examined in detail with a digital microscope with polarizer (Dino-lite Edge with 14:1 zoom ratio and magnification range of 10x-140x) (Fig. 3).

The general appearance of the clay suggests the use of a generic Nile silt for the manufacturing of these figurines (Van der Perre et al., forthcoming). The color of the unfired clay corresponds to Munsell codes 5YR 5/1-5/2-5/3. The figurines contain several inclusions in a fine-grained matrix, visible with the naked eye and approximately measuring $250-500 \mu \mathrm{m}$, suggesting temper 
might have been added to the raw material. All figurines contain mineral inclusions, while a vast amount contains inclusions of ashes and organic material, sometimes carbonized. Reed particles, chaff, carbonized barley and wood splinters are very common, even remnants of small (grape) and large seeds (Fabaceae family) are discernable (Van der Perre et al., forthcoming). Small voids in the clay are either the result of the degradation of organic inclusions or an irregular drying rate, indicative of a lack of preparation and blending of the clay. A large number of small, grey-white granules can be identified as carbonate particles but require further analyses. The edge of these inclusions appears smooth and rounded, lacking sharp corners, suggesting that the granules were not added as a temper but are part of the original raw material. Crushed sherds are also present, in some figurines only as small $(\sim 150-250 \mu \mathrm{m})$ orange-brown inclusions, while other figurines contain large fragments (c. up to $2 \mathrm{~cm}$, Van der Perre et al., forthcoming, fig. 8). Although the identification is often difficult, several figurines have small shell fragments as well.

Based on the quantity of, and the variation in the inclusions, the composition of the clay categorizes as Nile B1 or Nile B2 in the Vienna System (Arnold \& Bourriau, 1993). Even though the raw clay used for pottery is basically the same as the raw clay of the figurines, the former will have been modified by adding temper or by levitation to adapt it to the specialized needs of the potter. The figurines, however, did not require such preparation. The most relevant characteristic of the clay is its plasticity: the clay cannot be too plastic because that increases the risk of cracking due to excessive shrinkage (Hope, 1978). Although this resembles the adding of a temper by potters, the (intentional) addition of chaff and/or sand merely avoids cracking during drying, not during firing.

In regard to the surfaces, two types of pigment were used for the inscriptions. The majority of the figurines $(90 \%)$ is inscribed with a red ochre ink (hydrated iron oxides), while a carbon-based black pigment was used on the other objects (Blom-Boër, 1994; Lee and Quirke, 2000; Van der Perre et al., forthcoming).

\section{Methodology}


Studies on the utilization of handheld (or portable) X-ray fluorescence (hXRF/pXRF) for geological and archaeological materials also point out the drawbacks of the technique (Forster et al. 2011; Goren et al. 2011; Hunt \& Speakman 2015; Müskens et al. 2017; Young et al. 2016; Barone et al. 2011; Rowe et al. 2012; Pincé et al. 2018; Frahm 2018; Shackley 2011; Speakman et al. 2011; Shugar \& Mass 2012). Furthermore, few of these studies have successfully employed pXRF to address other clay-based materials in Egypt (Emmitt et al. 2018; Morgenstein \& Redmount 2005; Emery \& Morgenstein 2007). X-ray fluorescence (XRF) entails the emission of characteristic "secondary" (or fluorescent) X-rays from a material that has been excited by bombarding with high-energy X-rays. The phenomenon is used for elemental analysis of solids, powders or liquids. While the advantages of its portability and non-destructive nature are clear for vulnerable museum objects, it is important to gauge the effectiveness of the technique for the various elements measured on the surface of the ceramic objects. Therefore, the analysis of matrix matched standards and an assessment of precision and accuracy are invaluable for any pXRF study. Nevertheless the application of an energy dispersive technique allows for a relative comparison with other previous publications that employed XRF-based analysis of both ceramics and clays in Egypt.

Handheld equipment (Bruker Tracer III-SD) was used to determine the chemical composition of the clay of the selected figurines directly in museum context in order to identify (in)consistencies in this possibly unique assemblage. The instrument is equipped with an $\mathrm{Rh}$ anode $\mathrm{X}$-ray tube and a Peltier-cooled Silicon Drift Detector ( $145 \mathrm{eV}$ at MnKa). Spot size is approximately in the range of $5 \mathrm{~mm}^{2}$. Because of homogeneity considerations and the spot size of a pXRF device, analysis was concentrated on the flat backs of the figurines to achieve the most consistent bulk chemical data. The location of the measurements was carefully chosen on each figurine: the selected surfaces were clean of any post-depositional encrustations, visible inclusions or applied painted decoration. In general, the figurines themselves do not show a macroscopically heterogeneous texture and occasional visible larger grains were avoided. Matrix identifications of the different figurines are selected and can be described as exceedingly fine, thus offering potential for an adequate chemical determination of these clay materials. Post-excavation treatment products include the acrylic resin Paraloid B-72, diluted in Paraxylene. In most cases, 
it had been applied locally on these figurines and could thus be avoided (Van der Perre et al., forthcoming). However, some samples (E.7441, E.7444, E.7448, E.7472, E.7480) had been fully submerged in this resin. These were marked for possible additional further analysis of the obtained spectra if flagged as outliers. Measurements were taken in air for 120 seconds (de Winter et al. 2017), using a $150 \mu \mathrm{m} \mathrm{Cu}, 25 \mu \mathrm{m} \mathrm{Ti}$, and $300 \mu \mathrm{m} \mathrm{Al}$ filter, with beam conditions of $40 \mathrm{keV}$ and $14 \mu \mathrm{A}$. An empirical custom ceramic calibration (through multiple pressed pellet matrices) was used to semi-quantitatively assess the composition of the samples. Multiple readings were carried out on several objects to assess possible differences due to potential heterogeneity within the assemblage. Certified rock and soil standards are also analyzed periodically to check accuracy, precision and monitor for any machine drift during the analyses. Prior to quantifying the spectra, all data was evaluated through Bruker proprietary ARTAX software to determine the consistency of the matrices. The following set of international certified standards (powder in pressed pellet form) was used for quality control of the data: BIR-1 (basalt), SRG-1 (shale), GSP-2 (granodiorite), 98b (clay) and CRM667 (sediment) (supplementary table 2). Only elements with relative high squared correlation coefficients $\left(\mathrm{R}^{2}\right)$ in the calibration were retained for subsequent analysis: $\mathrm{Ca}=0.98, \mathrm{Sr}=0.96, \mathrm{Y}=0.98, \mathrm{Ti}=0.94$, $\mathrm{Mn}=0.96, \mathrm{Fe}=0.94, \mathrm{Ni}=0.99, \mathrm{Zn}=0.94, \mathrm{Zr}=0.94, \mathrm{Cr}=0.96, \mathrm{Rb}=0.99, \mathrm{Nb}=0.95$ and $\mathrm{K}=0.94$. Precision (both repeatability and reproducibility) of the measurements was controlled by a replicate analyses of standards 98b and CRM667 and is commonly assessed through the calculation of the relative standard deviation (\%RSD) (Abzalov 2008). All elements are below $10 \%$ RSD, except for Ni (14.50): i.e. Ca (2.55), Fe (1.84), K (6.71), Mn (4.99), Sr (1.18), Ti (5.60), $\mathrm{Zn}$ (9.79), $\mathrm{Nb}$ (8.04), Rb (2.94), Y (9.50) $\mathrm{Cr}$ (4.75) and $\mathrm{Zr}$ (2.06). Based on these values, especially $\mathrm{Ni}$ does not provide adequate results for quantification and therefore needs to be discarded for further interpretation.

The measurements were evaluated by an assessment of absolute data through bivariate and ternary diagrams, as well as by means of commonly applied multivariate statistical procedures such as hierarchical cluster analysis (HCA, for sample clustering) and principal component analysis (PCA). These statistical procedures are widely employed in a chemometric approach and provide a way to investigate complex datasets and thus isolate and also refine reference groups of pottery production. Prior to statistical processing the data is also log base transformed. 
This transformation allows for equal contribution of each element in chemometric procedures (Aitchinson 1986; Baxter \& Freestone 2006). As a linkage method and distance presentation in HCA, it was opted to use hierarchical Ward's clustering and squared Euclidian distance (as described by Johnson \& Wichern 2007). In contrast to other common methods, the distance between clusters is evaluated by an analysis of variance. Although cluster creation generally tends to be small-sized, this method endeavors to minimize the 'sum of squares' of any two (theoretical) clusters, formed at each step (Ward 1963). Principal Component Analysis (PCA) is widely applied as a pattern-recognition technique, by means of identifying subgroups in the compositional data. After PCA a visual output is often displayed in the form of a biplot. These represent reference axes as computed by the statistical procedure arranged by a decreasing order of variance. Both 'objects' and variables can easily be evaluated on the same set of axes. Therefore the contribution of specific elements to group separation can be observed together with the degree of variability. PCA is commonly both used as a tool to discover such subgroups or to assess the coherence of hypothetical groups suggested by other criteria, e.g. petrographic groups, archaeological context or decorational patterns,. For PCA, the log transformed data were analyzed through the covariance matrix. The optimal number of principal components can be assessed through the Krzanowski cross-validation (Eastman and Krzanowski, 1982). Factor analysis is also a main technique used for statistical analysis. This technique can simplify a complex data set by identifying several variables that might explain the dimensions associated with data variability as an added tool (Howarth \& and Govett, 1983). The contribution (or loading) of each factor is evaluated on the basis of associations between each variable. A varimax rotation was applied to the initial factor loadings in order to maximize the variance of the squared loadings.

The obtained cluster data and variability assessment can subsequently be utilized as a comparison to other XRF studies on Egyptian (raw) materials. Recently few studies were successfully conducted with $\mathrm{pXRF}$ or ED/WD-XRF, and clusters can be verified and put in context with published reference data from clays and ceramics from the region of Saqqara and beyond (Goren et al. 2011; Hamdan et al. 2014; Hamdan et al. 2018; Redmount \& Morgenstein 1996). Discriminant analysis will be further used to assess whether the identified typological groupings to which the chemical observations belong are distinct and if a systematic division 
occurs.

\section{Results}

pXRF analysis was conducted on 91 individual artefacts. Fragments too small or fragmentary to be assigned to a typological group were not taken into account for statistical analyses. First, the variability and consistency of the chemical composition of the dataset itself is provided through both statistical cluster procedures and bivariate diagrams. Reference studies dealing with chemically fingerprinting ceramics from Egypt utilized variable resolution techniques (ranging from ED-XRF to Neutron Activation Analysis - NAA) (Hancock et al. 1986; Morgenstein \& Redmount 2005), which provided an extensive set of variable elements to explore for provenance fingerprints. In the past, both major element ratios such as $\mathrm{SiO}_{2} / \mathrm{Al}_{2} \mathrm{O}_{3}$ as well as patterns involving heavy elements such as Th, Hf and $\mathrm{U}$ have been applied. Other studies pointed especially at the importance of strontium, titanium and zirconium for distinguishing Egyptian clays (McGovern 2000) as well as rubidium, strontium and iron for differentiating various Nile silt and marl deposits from other marine, volcanic or desert substrates (Morgenstein \& Redmount 2005; Emery \& Morgenstein 2007/1). Both light and very heavy elements are often difficult to detect and/or to quantify adequately by pXRF technology. As a result, focus will be drawn towards the feasibility of the Mid-Z elements (a.o. Sr, Rb, Zr, Ti, Y) for characterization of the assemblage. All statistical operations are based on $\log 10$ normalized data (Bishop \& Neff 1989; Baxter 2003).

To provide an initial overview of potential compositional groups within this figurine assemblage, a hierarchical cluster diagram (Fig. 4) in combination with factor analysis was constructed incorporating all measured figurines. In this way, groupings as well as the characterization of elements responsible for this variability can be analyzed (Degryse \& Braekmans 2014). Ward's agglomerative method was followed using squared Euclidean linkage distance. Only elements with relative consistent accuracy and precision results are retained: $\mathrm{Ca}, \mathrm{Fe}, \mathrm{K}, \mathrm{Sr}, \mathrm{Ti}, \mathrm{Zn}, \mathrm{Nb}, \mathrm{Rb}$, $\mathrm{Y}, \mathrm{Cr}$ and $\mathrm{Zr}$. As a result, three compositional groups are clustered together, labelled SEF (Saqqara Execration Figurines) I, SEF-II and SEF-III, representing three potential groups. Table 1 reports the mean and standard deviations of these groups. 
A second step is to evaluate which elements contribute to this differentiation and are responsible for the proposed group classification. Subsequently, reliability of these groups is assessed through factor analysis. Each factor represents a potential cluster of correlated variables within the dataset and is used to detect the structure of variance gain information about the interdependencies. This information can be utilized to identify associations of elements and their relation to the geological substrate. Retained factors are those with eigenvalues greater than 1 , as a factor needs to extract at least as much as the equivalent of one original variable, or is to be removed (Hakstian et al., 1982). As such, four factors pass this criterion in our dataset. The factor loadings, communalities and proportion of the variance explained by all determined factors are presented in table 2 .

The factor analysis yielded four factors, explaining $72.6 \%$ of the total variance in the data. Factor 1 is comprised of high by positive loadings $(>0.70)$ for $\mathrm{Fe}_{2} \mathrm{O}_{3}(\mathrm{~T}), \mathrm{TiO}_{2}, \mathrm{Y}$ and $\mathrm{Nb}$. Small positive contributions from $\mathrm{Zr}$ and $\mathrm{Rb}$ are given. Factor 2 contains high positive loadings for $\mathrm{CaO}$ and Sr. Factor 3 is dominated by positive loadings for $\mathrm{Cr}$ and $\mathrm{K}_{2} \mathrm{O}$, while Factor 4 shows positive loadings for $\mathrm{Zn}$ and $\mathrm{MnO}$. The variability of elements in the first factor seems to be controlled mainly by the presence of Fe-bearing minerals. This factor accounts for $33.7 \%$ of the total variance. Factor 2 and 3 are mainly controlled by the presence of respectively limestone and carbonate content, and feldspar and clay mineralogy. Since the study concerns unfired clay figurines, the alteration of $\mathrm{Rb}, \mathrm{Ca}, \mathrm{K}$ and $\mathrm{Na}$ would be less affected than it would be for ceramics fired above $800^{\circ} \mathrm{C}$ (Buxeda I Garrigós, 2001; Picon, 1991) and it could in this case also provide a direct link to the available clay raw materials.

Statistical clustering procedures defined the presence of three discrete cluster groups. Factor analysis determined the presence of three influential factors related mainly to a heavy mineral component, a limestone component, and the clay materials themselves. Chromium clearly separates SEF-III from the other two groups based on the higher abundance of $\mathrm{Cr}$, generally concentrated above $200 \mathrm{ppm}$. SEF-I on the other hand is mainly defined on the bases of lower strontium values, situated below $300 \mathrm{ppm}$. Unfortuantely, when combined with $\mathrm{TiO}_{2}$ for example, no clear pattern can be distinguished. Egyptian sediments are frequently enriched in $\mathrm{Ti}$ relating to the presence of detrital anatase and rutile (Takla \& Arafa 1975; Schneiderman 1995). 
In this graph, a large variability can be seen regarding the content of $\mathrm{TiO}_{2}$, which is equally disparate for all groups ranging approximately between 1.0 to $2.2 \mathrm{wt} . \%$. Apart from the $\mathrm{Sr}$ values, SEF-I also has systematically lower $\mathrm{Zn}$ values than encountered in the other two groups. Zinc content can vary widely in Egyptian soils, but is generally concentrated in heavy alluvial soils. In Egypt, the lowest amounts are found in calcareous and especially in sandy sediments (El-Kadi et al. 1973). While some overlap is clearly visible, both SEF-II and SEF-III contain generally more $\mathrm{Rb}$ and $\mathrm{Zr}$ than group SEF-I. Nile silt can contain a higher amount of Zr relating to a presence of aeolian sand into the floodplain silts. Elements such as iron (and the other major elements apart from $\mathrm{CaO}$ ) show a close coherence between the various groups with only minor differences. The highest values are concentrated in group SEF-II and SEF-III while the lowest are related to group SEF-I.

In summary, three groups are established on the basis of all measured and semi-quantified data. A detailed analysis of the influence of the different elements show that SEF-III is separated on the basis of the consistent relative high $\mathrm{Cr}$ abundances and to a lesser extent $\mathrm{Fe}_{2} \mathrm{O}_{3}$ and $\mathrm{TiO}_{2}$. Overall, SEF-I is more depleted in trace element content, while SEF-II has the highest $\mathrm{CaO}, \mathrm{K}_{2} \mathrm{O}$ and Sr values. Differentiation in trace and major elemental composition can thus be observed, especially regarding $\mathrm{Fe}_{2} \mathrm{O}_{3}, \mathrm{CaO}, \mathrm{Cr}$ and $\mathrm{Sr}$. Consequently, three statistical groups can be explained but they remain very closely connected and cannot be easily discriminated on the basis of sets of elemental bivariate diagrams. Therefore, the elemental composition of the assemblage itself points at one main resource group with several variations based on different ratios of clay and inclusions. These results will subsequently be compared to existing compositional and typological reference data.

\section{Discussion}

\subsection{A comparison to Egyptian clay raw materials}

The ceramics and clays of Egypt are well known for their relative homogeneity, belonging to one of the three large groups (Nile silt, marl or kaolin clay). Nile alluvium or Nile silt clays are generally calcium poor and have a fairly consistent composition throughout the entire Nile floodplain. These similar deposits are present since the Upper Pleistocene and therefore not only 
present in the current Nile valley, but in the entire floodplain (Bourriau et al. 2000; Michelaki \& Hancock 2013). Other major deposits for clay production are lime-rich marl clays, which are more concentrated in Upper Egypt and especially at sites such as Qena and El-Ballas, alongside several silty Nile muds (Bakr 1956; Bourriau et al. 2000; Shortland 2000; Alfred \& Harris 1962). Some studies on Egyptian (raw) materials were successfully conducted with pXRF and ED/WD$\mathrm{XRF}$ and the obtained data from the figurines can be tentatively compared to these reference data of both Egyptian clays and ceramics (Goren et al. 2011; Hamdan et al. 2014; Hamdan et al. 2018; Redmount \& Morgenstein 1996).

Reference values for the mineral resources and ceramics originate from various locations in the Saqqara-Memphis floodplain itself. In addition, selected clay cuneiform tablets from Amarna are added to the dataset as they are both concerned with XRF analysis of Egyptian clay sediments and ceramics (Hamdan et al. 2014; Goren et al. 2011). Relevant comparison materials to assess a local production of the figurines at Saqqara include ceramic reference data obtained from mixed "silt and gebel" and mixed silt-related modern ceramic material from Cairo and Badrashein respectively (Redmount \& Morgenstein 1996), contemporary clay reference material from the recent SAQA 22 floodplain core at Saqqara (more specifically Unit IV) (Hamdan et al. 2018), and reference clays from the Saqqara-Memphis area (Hamdan et al. 2014) and Amarna (Goren et al. 2011).

The first two principal components explain $\sim 75 \%$ of the total variance. The score plot of the PCA shows that all three figurine groups are correlated with each other (Fig. 5). A clear distinction can be made between all marl and Nile silt raw materials in Saqqara and beyond. When compared to the figurines studied here, all SEF groups are situated between the Nile silt and marl deposits at Saqqara, but especially seem to show similar values to the clays in the recent floodplain core and modern ceramics from nearby Badrashein. Based on the absolute values, the general characteristics of this cluster group would rather point in the direction of a Nile silt containing elements of marl and fits with the use of the deposits in the immediate surroundings of Saqqara. Hence, all figurines clustered in varieties SEF I-III appear to point at a (mixed) Nile silt origin of raw materials, while a pure marl source would be rather unlikely. The attested variability within the assemblage however, signifies the absence of a dedicated 
preparation of the clay bed utilized for ceramic production but might also incorporate different local varieties of Nile silt from the Saqqara floodplain. However, as noted by Riederer (1989), Bourriau et al. (2000), and more recently also discussed by Spataro et al. (2018), Old Kingdom Nile silt pottery at Dashur and Saqqara have been characterized by a high calcium carbonate content, which seems to be replicated here as well. Interestingly, contrary to those from Amarna, marl deposits from Saqqara are significantly enriched in rubidium, and the modern mixed ceramics from Cairo are heavily influenced by calcium carbonates.

$\mathrm{Zn}$ or $\mathrm{Cr}$ are not incorporated in these graphs because these elements were not provided in all the reference studies. Chromium, however, is the major element that distinguished SEF-III from the other two groups. Despite these differences, the general build-up of the figurines does not point at different clay sources, but rather at the use of one source with some inherent variability.

There is a significant consistency of the figurine data with the reference data obtained for Nile silt clays. However, the figurines itself prove to be enriched in calcium carbonate content, contrary to what is considered generic Nile silt clay geochemistry. Potters commonly mix and prepare Nile clays, but in the case of unfired figurines the shape might need to be consolidated by an additional temper or a mixture of Nile silt clay with calcium carbonates. Therefore, it would not be surprising that a clay from a deposit enriched in carbonate materials is added in minor quantities to an otherwise finer Nile silt composition. Alternatively, in the Nile valley to the south of Cairo, marl clays are found that relate to the cliffs and desert that encompasses the Nile valley (Redmount \& Morgenstein 1996). These can provide a direct influx of carbonate material and thus a more natural mixture. As pointed out by other authors as well (Riederer 1989, Bourriau et al. 2000; Spataro et al. 2018), this data would also support the observation of a more carbonate enriched Nile silt material in the vicinity of Saqqara. This additionally has the potential to be a good marker for provenancing. Given the close geochemical consistency with both modern ceramics from Badrashein and contemporary Nile floodplain deposits, the data obtained for the figurines would suggest a localized production in the close vicinity of Saqqara within the Nile floodplain itself.

\subsection{Typological considerations versus composition}


At first sight, the RMAH assemblage contains two groups: large figurines $(>30 \mathrm{~cm})$, carrying the nearly complete version of the execration texts (including references to non-Egyptian enemies), and a second group of smaller figurines (c. 10-15 cm), bearing references to Egyptian individuals and 'negative things' in general (Fig. 1). Based on the research conducted during the project (Delvaux et al., 2017), this general division was refined into five types: Types A-E, of which E contains two subtypes (E1-E2). This division in subtypes is based on morphological differences and, as such, not directly relevant for the analysis of the chemical composition of the assemblage. Therefore, the two subgroups were analyzed together as a homogeneous type, dubbed Type E.

As stated above, an additional research axis was to analyze whether the proposed typology is mirrored in the clay composition of the assemblage. The following analyses used the absolute compositional values and discriminant analysis to assess whether there is any differentiation in composition related to typological group attribution. A ternary diagram using iron, strontium and rubidium (Fig. 6) shows the composition of these typological groups opposed to published reference values from Hamdan et al. (2014; 2018), Redmount \& Morgenstein (1196) and Goren et al. (2011). These elements are selected due to their previous successful compositional discrimination abilities in other parts of Egypt. All groups show very similar and consistent values. It is apparent that the general resources of all different typological groups are quite homogenous and point at a Nile silt with elevated amounts of carbonate materials. Nile silt clays and ceramics generally contain around $2.5-4 \mathrm{wt} . \%$ of $\mathrm{CaO}$, while marl clays and ceramics around Saqqara contain above $10 \mathrm{wt} . \% \mathrm{CaO}$. While a marl source can be excluded, this diagram points at a (Saqqara) Nile silt origin, but richer in calcium carbonates than expected. Strikingly, it has a very close consistency with signatures obtained from modern pottery produced at nearby Badrashein as reported by Redmount and Morgenstein (1996) (fig 6).

Finally, discriminant analysis assesses whether these typological group denominations can be distinguished from each other based on the analyzed elements in this dataset (Fig. 7). Based on Fig. 7, it can be concluded that the morphological typology is not clearly mirrored in the clay composition. The only exception seems to be Type A, which has a chemical pattern that slightly differs from the others. These figurines, being noticeably larger $(>30 \mathrm{~cm})$ and produced with greater care and skill, are thus not only a clearly identifiable type based on morphological 
characteristics, but also in clay composition. It is possible that the clay was processed in a slightly different way, since the size of the figurines required an adapted fabric plasticity. Differentiation between the other types is not as evident as in the case of the Type A figurines. A certain overlap is noticeable between the chemical composition of Types $\mathrm{B}$ and $\mathrm{C}$, while the values of Type E are more spread out. Figurines in Type A can be distinguished from those in Types B and D, but not as clearly from certain figurines attributed to Types C and E.

There are several possible explanations for these variations, related to the composition of the raw material itself. Even within a single clay bed the chemical composition of the clay is never entirely homogeneous. When the clay was collected from another zone within the same clay bed, this is potentially mirrored in the composition. Another possible factor influencing the composition might be the time of collecting. It is possible that the production of the figurines took place at different moments in time, depending on certain ritual prescriptions. On the other hand, the minor differences may also reflect a different approach in clay preparation and processing, indicating the existence of different "workshops" or creators. These explanations need further research and present new avenues for research.

\section{Conclusions}

The overall goal of this project was to determine whether a single clay source was used for the production of these figurines, whether the morphological typology was mirrored in the clay composition and whether the raw materials are consistent with the production of local ceramics. The very nature of these figurines, being unfired, allows a direct comparison with clay raw materials and addresses the suitability of non-destructive XRF analysis on Egyptian ceramic materials in a museum setting.

In general, the chemical fingerprint of the figurines shows a fairly homogenous picture of similar (Nile) sediments, especially those analyzed in the Saqqara floodplain itself. Minor variations within the assemblage point at three different subgroups, but these variations appear limited and rather indicate that a similar type of clay raw material was used. The variations are moreover too discrete to clearly indicate distinct provenances. The chemical differentiation of groups SEF I-III 
can be explained by changes or modifications in clay preparation, mixing and processing, or by natural variations within the raw materials due to influx of carbonate deposits into the floodplain clays. The chemical characteristics based on discriminating elements as iron, rubidium and strontium indicate it is not likely that common marl or Nile silt clay sources for pottery production were utilized. Instead, the consistency in these compositions rather point at an untreated floodplain or 'mixed' resource.. This implies a mixture of Nile silt and marl clay, that is to sayNile silt to which calcium carbonates/marl clays have been intentionally added or which have naturally precipitated in the sediment. Whether this clay recipe is natural or man-made is difficult to assess at this point, but it must be kept in mind that extensive preparation or mixture procedures for these materials were probably deemed unnecessary because of the intrinsic nature of the figurines themselves, namely as objects to be ritually discarded. More likely, the raw materials derived from the periphery of clay sources, such as Nile silt clay with washed-in desert and sedimentary soil debris. Sources in the area of Saqqara can be enriched in carbonates. Recent analyses by Hamdan et al. 2018 was conducted within the floodplain on clay strata (Unit IV) contemporary with the production period of the figurines. The analyses show a high geochemical consistency and suggest that this resource might have been the main source for the production of the figurines under study. At this point, since chemical analyses are not frequently used in Egyptian pottery studies and the differences between the three groups are not visible with the naked eye, the clay used for all figurines remains classified as a Nile B1/B2 in the Vienna system.

Apart from the large figurines (Type A), which had been produced with more care, the chemical composition of the clay is hardly mirrored in the morphological typology. While for Type A figurines this might be linked to different clay processing due to the size of the figurines, this is not valid for the other types. The majority of the assemblage was made with a very similar clay, but even within the same morphological type the chemical pattern alters. On the one hand, this suggests that various types were made from the same batch of clay, and on the other hand that likely not all figurines were created simultaneously by one individual or workshop.

The paper also confirms the applicability of the presented approach for the characterization of unfired clay and the possibility for provenance determinations of these extremely fragile clay 
artefacts, especially those housed in museums, where sampling is not an option. While the restricted set of reference data for this particular assemblage currently impedes a direct one-onone provenancing of the execration figurines, the applied approach does prove that a proper grouping of objects based on their chemical composition and general provenance is feasible and that it can point in the direction of a potential and suitable clay source. In this particular case all data confirms a consistent local production in Saqqara. Additionally, the data correlates well with the specific Saqqara clay deposits and modern Saqqara ceramics as previously determined, which contributes to the determination of a Saqqara geochemical signature.

In a later stage, when additional data might become available, e.g. more geological samples of specific regions, the obtained data can be compared and linked to more precise locations of the newly analyzed samples. Therefore, the importance of the presented assemblage for potential future ceramic and clay studies is evident.

\section{Acknowledgements}

This research was funded by the Belgian Science Policy Office BELSPO through the programs BRAIN.be (project BR/121/PI/EES), the Interuniversity Attraction Poles Program (project IAP VII/14: Greater Mesopotamia: Reconstruction of its Environment and History) and the Materials in Art and Archaeology group at TU Delft. The authors thank Luc Delvaux, curator of the RMAH's collection of ancient Egyptian art, for making the objects available for analysis, and France Ossieur, ceramics conservator at the museum, for her assistance and insights. Stan Hendrickx (MAD Faculty Hasselt) and Bettina Bader (Austrian Academy of Sciences, Vienna) are acknowledged for their advice regarding Egyptian ceramic materials and mineral resources. We would also like to thank the anonymous referees for their comments and improvements to the manuscript.

\section{Bibliography}

Abzalov, M., 2008. Quality Control of Assay Data: A Review of Procedures for Measuring and Monitoring Precision and Accuracy. Exploration and Mining Geology, 17(3-4), pp.131-144.

Abdalla, A., 1992, The Cenotaph of the Sekwaskhet Family, Journal of Egyptian Archaeology 78, 93-111. 
Alfred, L. \& Harris, J.W., 1962. Ancient Egyptian materials and industries. London: Arnold.

Allen, R.O., Hamroush, H., Hoffman, M.A., 1989, Archaeological implications of differences in the composition of Nile sediments, in: R.O. Allen (Ed.), Archaeological Chemistry IV, Washington: American Chemical Society, 33-56.

Arnold, D., Bourriau, J. (Eds.), 1993, An Introduction to Ancient Egyptian Pottery (Deutsches archäologisches Institut. Abteilung Kairo. Sonderschriften 17), Mainz am Rhein: Philipp von Zabern.

Aitchinson., J.,1986, The Statistical Analysis of Compositional Data. London: Chapman and Hall

Bakr, M.Y., 1956, Pottery Technique: An Introduction to Egyptian Ceramic Industry. I. Prehistoric and Dynastic Pottery. Silicates Industrielle 21, 513-515

Ballet, P. \& Picon, M., 1990. La production céramique. Balat III. Les ateliers de potiers d'AynAsil. Fin de l'Ancien Empire, Première Période Intermédiaire. G. Soukiassian, M. Wuttman, and L. Pantalacci (eds.), pp.75-157.

Barone, G., Crupi, V., Longo, F., Majolino, D., Mazzoleni, P., Spagnolo, G., Venuti, V., Aquilia, E., 2011. Potentiality of non-destructive XRF analysis for the determination of Corinthian B amphorae provenance. X-Ray Spectrometry, 40(5), pp.333-337.

Baxter, M.J., 2003. Statistics in archaeology, London: Arnold.

Baxter M.J., Freestone I.C., 2006. Log-ratio compositional analysis in Archaeometry, Archaeometry 48, 511-31.

Bishop, R.L. \& Neff, H., 1989. Compositional Data Analysis in Archaeology. In Archaeological Chemistry IV. Advances in Chemistry. American Chemical Society, pp. 57-86.

Blom-Boër, I., 1994, Zusammensetzung altägyptischer Farbpigmente und ihre Herkunftslagerstätten in Zeit und Raum, Oudheidkundige Mededelingen uit het Rijksmuseum van Oudheden te Leiden 74, 55-107.

Bourriau, J.D. \& Nicholson, P.T., 1992. Marl Clay Pottery Fabrics of the New Kingdom from Memphis, Saqqara and Amarna. The Journal of Egyptian archaeology, 78(1), pp.29-91.

Bourriau, J., Smith, L. \& Nicholson, P.T., 2000. New Kingdom pottery fabrics: Nile clay and mixed Nile/marl clay fabrics from Memphis and Amarna.

Bourriau, J., Nicholson, P., Rose, P., 2000, Pottery, in: P. Nicholson, I. Shaw (Eds.), Ancient Egyptian Materials and Technology, Cambridge: University Press, 121-147. 
Buxeda I Garrigós, J., Kilikoglou, V., Day, P.M., 2001, Chemical and mineralogical alteration of ceramics from late Bronze Age kiln at Kommos, Crete: The effect on the formation of a reference group, Archaeometry 43, 349-371.

Degryse, P. \& Braekmans, D., 2014. 14.14 - Elemental and Isotopic Analysis of Ancient Ceramics and Glass A2 - Holland, Heinrich D. In K. K. Turekian, ed. Treatise on Geochemistry (Second Edition). Oxford: Elsevier, pp. 191-207.

Delvaux L., Hameeuw H., Van der Perre A., Boschloos V., Ossieur F., Vandermeulen B., Proesmans M., Braekmans D. 2017, Conservation, IR, UV and 3D-Imaging: The Egyptian Execration Statuettes Project (EES) - Final Report, Belgian Science Policy 2017, Brussels, pp 64.

Eastment, H. T., \& Krzanowski, W. J. (1982, February) Cross-validatory choice of the number of components from a principal components analysis, Technometrics, 24 (1), 73-77.

El-Kadi, M.A. et al., 1973. Available zinc status in the soils of Egypt as evaluated by chemical and biological methods. Journal of soil science of the United Arab Republic. Available at: http://agris.fao.org/agris-search/search.do?recordID=US201303143517.

Egyptian Geological Survey and Mining Authority, 1981. Geological map of Egypt. Cairo: Ministry of Industry and Mineral Resources.

Emery, V.L. \& Morgenstein, M., 2007/1. Portable EDXRF analysis of a mud brick necropolis enclosure: evidence of work organization, El Hibeh, Middle Egypt. Journal of archaeological science, 34(1), pp.111-122.

Emmitt, J.J. et al., 2018. Sourcing without sources: Measuring ceramic variability with pXRF. Journal of Archaeological Science: Reports, 17, pp.422-432.

Forster, N. et al., 2011. Non-destructive analysis using PXRF: methodology and application to archaeological ceramics. X-Ray Spectrometry, 40(5), pp.389-398.

Frahm, E., 2018. Ceramic studies using portable XRF: From experimental tempered ceramics to imports and imitations at Tell Mozan, Syria. Journal of archaeological science, 90, pp.12-38.

Goren, Y., Mommsen, H. \& Klinger, J., 2011. Non-destructive provenance study of cuneiform tablets using portable X-ray fluorescence (pXRF). Journal of archaeological science, 38(3), pp.684-696.

Hakstian, A. R., Rogers, W. D., Cattell, R. B., 1982, The behavior of numbers of factors rules with simulated data, Multivariate Behavioural Research 17, 193-219.

Hamdan, M.A. et al., 2014. Ancient Egyptian Pottery from the Subsurface Floodplain of the Saqqara-Memphis Area: Its Mineralogical and Geochemical Implications. Archaeometry, 56(6), pp.987-1008. 
Hamdan, M.A. et al., 2018. Source of Nile sediments in the floodplain at Saqqara inferred from mineralogical, geochemical, and pollen data, and their palaeoclimatic and geoarchaeological significance. Quaternary international. https://doi.org/10.1016/j.quaint.2018.02.021

Hamdan, M.A., 2000. Subsurface late Pleistocene Nile flood plain sediments of Saqqara area: paleoenvironmental interpretations. Journal of Sedimentology of Egypt, 8, pp.243-254.

Hamroush, H. and Zeid, H.A., 1990, Petrological and chemical analyses of some neolithic ceramics from el Omari, Egypt, in: F. Debono and B. Mortensen, El Omari: a neolithic settlement and other sites in the vicinity of Wadi Hof, Helwan, Deutsches archäologisches Institut. Abteilung Kairo. Archäologische Veröffentlichungen 82, Mainz: von Zabern, 117-128.

Hancock, R.G.V., Millet, N.B. \& Mills, A.J., 1986. A rapid INAA method to characterize Egyptian ceramics. Journal of archaeological science, 13(2), pp.107-117.

Hope, C., 1978, Excavations at Malkata and the Birket Habu 1971-1974: Jar Sealings and Amphorae of the 18th Dynasty: A Technological Study (=Egyptology Today 2, 5), Warminster: Aris and Phillips.

Howarth, R.J., Govett, G.J.S. (Eds.), 1983, Handbook of Exploration Geochemistry 2: Statistics and Data Analysis in Geochemical Prospecting, Amsterdam: Elsevier.

Hunt, A.M.W. \& Speakman, R.J., 2015. Portable XRF analysis of archaeological sediments and ceramics. Journal of archaeological science, 53, pp.626-638.

Johnson, R.A., Wichern, D.W., 2007 (6th ed.), Applied multivariate statistical analysis, New Jersey: Prentice Hall.

Kilikoglou, V., Maniatis, Y., Grimanis, A.P., 1988, The effect of purification and firing of clays on trace elements provenance studies, Archaeometry 30 (1), 37-46.

Lee, L., Quirke, S., 2000, Painting Materials, in: P. Nicholson, I. Shaw (Eds.) Ancient Egyptian Materials and Technology. Cambridge: University Press, 104-120.

McGovern, P.E., 2000. The foreign relations of the "Hyksos": a neutron activation study of Middle Bronze Age pottery from the Eastern Mediterranean, British Archaeological Reports Ltd.

Michelaki, K. \& Hancock, R.G.V., 2013. Reassessment of elemental concentration data of sediments from the western delta of the Nile River. Open Journal of Archaeometry, 1(1), p.2.

Morgenstein, M. \& Redmount, C.A., 2005. Using portable energy dispersive X-ray fluorescence (EDXRF) analysis for on-site study of ceramic sherds at El Hibeh, Egypt. Journal of archaeological science, 32(11), pp.1613-1623.

Moustafa, A., 1988. Wrench tectonics in the North Western Desert of Egypt (Abu Roash area, southwest of Cairo). Middle East Research Center, Ain Shams University, Earth Sciences Series, v. 2, p. 1-16. 
Müskens, S. et al., 2017. Egyptian sculptures from Imperial Rome. Non-destructive characterization of granitoid statues through macroscopic methodologies and in situ XRF analysis. Archaeological and anthropological sciences, pp.1-16.

Nordstrom, H.-A., Bourriau, J., 1993, Ceramic technology: clays and fabrics, in: D. Arnold, J. Bourriau (Eds) An Introduction to Ancient Egyptian Pottery, Mainz am Rhein: Philipp Von Zabern, 143-190.

Ownby, M. \& Griffiths, D., 2009. Issues of Scum: Technical Analyses of Egyptian Marl C to Answer Technological Questions. Ägypten und Levante / Egypt and the Levant, 19, pp.229-239.

Padilla, R., Espen, P.V. \& Torres, P.P.G., 2006. The suitability of XRF analysis for compositional classification of archaeological ceramic fabric: A comparison with a previous NAA study. Analytica chimica acta, 558(1-2), pp.283-289.

Papa, G., 2003. Site environmental analysis. In The North Saqqara archaeological site. PLUSPisa University Press, pp. 1000-1025.

Picon, M., 1991, Quelques observations complémentaires sur les altérations de composition des céramiques au cours du temps: cas de quelques alcalins et alcalino-terreux, Revue d'Archéométrie 15, 117-22.

Pincé, P. , Braekmans, D., Abdali, N., De Pauw, E., Amerilad, S., Vandenabeele, P., 2018. Development of ceramic production in the Kur River Basin (Fars, Iran) during the Neolithic. A compositional and technological approach using X-ray fluorescence spectroscopy and thin section petrography. Archaeological and anthropological sciences.

https://doi.org/10.1007/s12520-018-0598-6.

Posener, G., 1939, Nouvelles listes de proscription (Ächtungstexte) datant du Moyen Empire, Chronique d'Égypte 27, 39-46.

Posener, G., 1940, Princes et pays d'Asie et de Nubie. Textes hiératiques sur des figurines d'envoûtement du Moyen Empire, Bruxelles: Fondation Égyptologique Reine Élisabeth.

Rapp, G., Hill, C.L., 2006. Geoarchaeology. The Earth-Science Approach to Archaeological Interpretation, New Haven - London, Yale University Press.

Redmount, C.A. \& Morgenstein, M.E., 1996. Major and Trace Element Analysis of Modern Egyptian Pottery. Journal of archaeological science, 23(5), pp.741-762.

Rowe, H., Hughes, N. \& Robinson, K., 2012. The quantification and application of handheld energy-dispersive $\mathrm{x}$-ray fluorescence (ED-XRF) in mudrock chemostratigraphy and geochemistry. Chemical geology, 324-325, pp.122-131.

Riederer J. 1989., The microscopic analysis of Egyptian pottery from the Old Kingdom. In: Schoske S (ed) Akten des vierten Internationalen Ägyptologen-Kongresses München 1985. Studien zur altägyptischen Kultur Beihefte I. Helmut Buske Verlag, Hamburg, pp 221-230. 
Ritner, R.K, 1993, The Mechanics of Ancient Egyptian Magical Practice (Studies in Ancient Oriental Civilization 54), Chicago: Oriental Institute.

Said, R., 1975, Subsurface geology of Cairo area (Mémoires de l'Institut d'Egypte 60), Le Caire: Institut égyptien.

Said, R., 1990, The geology of Egypt, Rotterdam: Balkema.

R. Schiestl, A. Seiler, 2012a, Handbook of the Pottery of the Egyptian Middle Kingdom. Vol. I: The Corpus Volume (Österreichische Akademie der Wissenschaften. Denkschriften der Gesamtakademie, Band LXXII), Vienna: Österreichischen Akademie der Wissenschaften.

R. Schiestl, A. Seiler, 2012b, Handbook of the Pottery of the Egyptian Middle Kingdom. Vol. II: The Regional Volume (Österreichische Akademie der Wissenschaften. Denkschriften der Gesamtakademie, Band LXXII), Vienna: Österreichischen Akademie der Wissenschaften.

Schneiderman, J.S., 1995. Detrital opaque oxides as provenance indicators in River Nile sediments. Journal of Sedimentary Research, 65(4a), pp.668-674.

Shackley, S. M. ed., 2011. X-Ray Fluorescence Spectrometry (XRF) in Geoarchaeology: Springer New York.

Shortland, A.J., 2000. Vitreous materials at Amarna: the production of glass and faience in 18th Dynasty Egypt, British Archaeological Reports Ltd.

Shugar, A.N. \& Mass, J.L., 2012. Handheld XRF for Art and Archaeology, Leuven University Press.

Spataro, M., Mommsen, H. \& Villing, A., 2018. Making pottery in the Nile Delta: ceramic provenance and technology at Naukratis, 6th-3rd centuries BC. Archaeological and anthropological sciences. Available at: https://doi.org/10.1007/s12520-017-0584-4.

Speakman, R.J. et al., 2011. Sourcing ceramics with portable XRF spectrometers? A comparison with INAA using Mimbres pottery from the American Southwest. Journal of archaeological science, 38(12), pp.3483-3496.

Stanley, D.J. \& Jonathan G. Wingerath, 1996. Clay Mineral Distributions to Interpret Nile Cell Provenance and Dispersal: I. Lower River Nile to Delta Sector. Journal of Coastal Research, 12(4), pp.911-929.

Takla, M.A. \& Arafa, E.H., 1975. The mineralogy of the sand dunes between Minya and Dairut, Egypt. Tschermaks mineralogische und petrographische Mitteilungen, 22(2), pp.164-173.

Van der Perre, A., Braekmans, D., Boschloos, V., Ossieur F., Hameeuw, H. and L. Delvaux (forthcoming), 'The Egyptian Execration Figurines of the Royal Museums of Art and History, Brussels: Conservation, Pigments and Digitisation', Bulletin des Musées royaux d'Art et d'Histoire, Bruxelles 85, 5-38. 
Ward, J.H., 1963. Hierarchical Grouping to Optimize an Objective Function. Journal of the American Statistical Association, 58(301), pp.236-244.

de Winter, N.J. et al., 2017. Trace element analyses of carbonates using portable and micro-Xray fluorescence: performance and optimization of measurement parameters and strategies. Journal of analytical atomic spectrometry, 32(6), pp.1211-1223.

Yehia, A., 1985, Geological structures of the Giza pyramids plateau, Scientific Research Series of the Middle East Research Center, Ain Shams University, Egypt 5, 100-120.

Young, K.E. et al., 2016. A review of the handheld X-ray fluorescence spectrometer as a tool for field geologic investigations on Earth and in planetary surface exploration. Applied geochemistry: journal of the International Association of Geochemistry and Cosmochemistry, 72, pp.77-87.

Youssef, M. et al., 1984. Geological studies on the Sakkara area, Egypt. Neues Jahrbuch für Geologie und Paläontologie-Abhandlungen, pp.125-144. 


\begin{tabular}{|c|c|c|c|c|c|c|c|c|c|c|c|c|c|c|c|c|c|}
\hline & Location & Reference & Type & & $\begin{array}{r}\mathrm{K}_{\mathbf{2}} \mathrm{O} \\
\text { wt.\% } \\
\end{array}$ & $\begin{array}{r}\mathrm{CaO} \\
\text { wt.\% } \\
\end{array}$ & $\begin{array}{r}\mathrm{TiO}_{2} \\
\text { wt.\% } \\
\end{array}$ & $\begin{array}{l}\text { Mno } \\
\text { wt.\% } \\
\end{array}$ & $\begin{array}{c}\mathrm{Fe}_{2} \mathrm{O}_{3}(\mathrm{~T}) \\
\text { wt.\% }\end{array}$ & $\begin{array}{c}\mathrm{Zn} \\
\mathrm{ppm}\end{array}$ & $\begin{array}{c}\mathbf{N i} \\
\mathrm{ppm}\end{array}$ & $\begin{array}{c}\mathbf{R b} \\
\mathrm{ppm}\end{array}$ & $\begin{array}{c}\mathrm{Sr} \\
\mathrm{ppm}\end{array}$ & $\begin{array}{c}\mathrm{Y} \\
\mathrm{ppm}\end{array}$ & $\begin{array}{c}\mathrm{Zr} \\
\mathrm{ppm} \\
\end{array}$ & $\begin{array}{c}\mathbf{N b} \\
\mathrm{ppm}\end{array}$ & $\begin{array}{c}\mathrm{Cr} \\
\mathrm{ppm}\end{array}$ \\
\hline \multirow[t]{2}{*}{ Group SEF-I $(n=22)$} & Saqqara & & Unfired figurine & mean & 0.97 & 6.15 & 1.31 & 0.15 & 7.17 & 107 & 41 & 27 & 264 & 54 & 201 & 15 & 122 \\
\hline & & & & s.d. & 0.20 & 1.31 & 0.31 & 0.06 & 1.31 & 53 & 19 & 2 & 20 & 16 & 21 & 3 & 47 \\
\hline \multirow[t]{2}{*}{ Group SEF-II $(n=54)$} & Saqqara & & Unfired figurine & mean & 1.08 & 8.33 & 1.58 & 0.21 & 8.62 & 154 & 56 & 34 & 346 & 69 & 234 & 18 & 122 \\
\hline & & & & s.d. & 0.24 & 1.49 & 0.30 & 0.09 & 1.31 & 57 & 23 & 4 & 29 & 16 & 23 & 3 & 45 \\
\hline \multirow[t]{2}{*}{ Group SEF-III $(\mathrm{n}=15)$} & Saqqara & & Unfired figurine & mean & 0.99 & 7.59 & 1.77 & 0.20 & 9.10 & 132 & 55 & 34 & 331 & 72 & 243 & 19 & 257 \\
\hline & & & & s.d. & 0.21 & 1.59 & 0.37 & 0.06 & 1.39 & 32 & 19 & 3 & 44 & 19 & 34 & 2 & 59 \\
\hline EgypA & Amarna & Goren et al. 2011 & Esna Marl & mean & 1.02 & 20.85 & 0.57 & 0.09 & 5.46 & - & - & 10 & 322 & - & 152 & 17 & - \\
\hline Egyp B & Amarna & Goren et al. 2011 & Marly Clay & mean & 1.61 & 4.60 & 1.17 & 0.20 & 7.88 & - & - & 10 & 301 & - & 187 & 23 & - \\
\hline EgypC & Amarna & Goren et al. 2011 & Marly Clay & mean & 1.17 & 11.61 & 0.85 & 0.12 & 7.49 & - & - & 10 & 276 & - & 197 & 23 & - \\
\hline EgypD & Amarna & Goren et al. 2011 & Nile Silt & mean & 1.29 & 2.69 & 1.07 & 0.15 & 9.49 & - & - & 19 & 116 & - & 269 & 26 & - \\
\hline EgypBC & Amarna & Goren et al. 2011 & Marly Clay & mean & 1.39 & 7.43 & 0.98 & 0.15 & 7.71 & - & - & 10 & 286 & - & 193 & 23 & - \\
\hline Saqqara & Saqqara-Memphis & Hamdan et al. 2014 & Nile Silt & mean & 1.24 & 4.02 & 1.89 & 0.19 & 12.00 & - & 89 & 63 & 216 & 33 & 251 & 26 & 129 \\
\hline $\mathrm{N}-2$ & Saqqara-Memphis & Hamdan et al. 2014 & Nile Silt & mean & 1.25 & 3.51 & 1.91 & 0.19 & 12.00 & - & 89 & 63 & 211 & 32 & 250 & 27 & 137 \\
\hline$N-3$ & Saqqara-Memphis & Hamdan et al. 2014 & Nile Silt & mean & 1.26 & 4.03 & 1.78 & 0.17 & 11.00 & 78 & 61 & 48 & 161 & 24 & 174 & 20 & 136 \\
\hline $\mathrm{N}-4$ & Saqqara-Memphis & Hamdan et al. 2014 & Nile Silt & mean & 1.34 & 2.98 & 1.37 & 0.10 & 7.00 & 76 & 42 & 48 & 235 & 23 & 255 & 17 & 140 \\
\hline D-1 & Saqqara-Memphis & Hamdan et al. 2014 & Desert Marl Clay & mean & 1.15 & 12.86 & 1.05 & 0.02 & 8.00 & 113 & 24 & 56 & 477 & 26 & 210 & 29 & 86 \\
\hline D-2 & Saqqara-Memphis & Hamdan et al. 2014 & Desert Marl Clay & mean & 1.25 & 10.73 & 1.66 & 0.09 & 9.00 & 109 & 73 & 79 & 167 & 39 & 263 & 39 & 117 \\
\hline Cer M-15 & Saqqara-Memphis & Hamdan et al. 2014 & Nile Silt I & mean & 1.86 & 4.09 & 1.63 & 0.17 & 9.00 & 122 & 109 & 50 & 304 & 30 & 235 & 23 & 122 \\
\hline Cer M-28 & Saqqara-Memphis & Hamdan et al. 2014 & Nile Silt II & mean & 3.04 & 3.04 & 1.45 & 0.13 & 7.14 & 69 & 58 & 31 & 231 & 19 & 273 & 18 & 169 \\
\hline Cer M-11 & Saqqara-Memphis & Hamdan et al. 2014 & Marl I & mean & 1.72 & 10.00 & 1.07 & 0.15 & 7.00 & 78 & 52 & 45 & 577 & 29 & 269 & 24 & 103 \\
\hline Cer M-23 & Saqqara-Memphis & Hamdan et al. 2014 & Marl II & mean & 2.06 & 18.41 & 0.68 & 0.13 & 5.00 & 77 & 43 & 88 & 308 & 25 & 140 & 19 & 66 \\
\hline Cer M-21 & Saqqara-Memphis & Hamdan et al. 2014 & Mixed & mean & 1.62 & 3.33 & 1.88 & 0.14 & 10.00 & 128 & 78 & 58 & 281 & 35 & 300 & 29 & 153 \\
\hline SAQA 22 & Saqqara Floodplain & Hamdan et al. 2018 & Nile Silt & mean & 1.39 & 9.18 & 1.05 & 0.19 & 6.85 & 64 & 103 & 36 & 485 & - & 216 & - & 92 \\
\hline Cairo 50 & Cairo & Redmount and Morgenstein 1996 & Mixed & mean & 1.10 & 21.90 & 1.15 & 0.09 & 6.70 & 205 & 42 & 17 & 713 & 25 & 288 & 13 & 300 \\
\hline Cairo 51 & Cairo & Redmount and Morgenstein 1996 & Mixed & mean & 1.43 & 17.40 & 1.42 & 0.12 & 8.61 & 211 & 52 & 27 & 677 & 30 & 296 & 19 & 240 \\
\hline Cairo 39 & Cairo & Redmount and Morgenstein 1996 & Mixed & mean & 1.16 & 20.40 & 1.37 & 0.10 & 7.60 & 165 & 50 & 12 & 592 & 25 & 283 & 15 & 500 \\
\hline 16.1 & Badrashein & Redmount and Morgenstein 1996 & Mixed & mean & 3.02 & 7.85 & 1.78 & 0.16 & 9.82 & 241 & 65 & 42 & 405 & 33 & 272 & 20 & 280 \\
\hline
\end{tabular}

Table 1: Mean and standard deviations of the statistically defined groups in addition to selected reference materials from Goren et al. (2011), Hamdan et al. $(2014,2018)$ and Redmount and Morgenstein (1996).

\begin{tabular}{|c|c|c|c|c|}
\hline & Factor - 1 & Factor - 2 & Factor - 3 & Factor - 4 \\
\hline $\mathbf{K}_{\mathbf{2}} \mathbf{O}$ & 0.317556 & 0.137589 & 0.755983 & 0.028258 \\
\hline $\mathbf{C a O}$ & -0.113705 & 0.931006 & 0.052177 & 0.04483 \\
\hline $\mathrm{TiO}_{\mathbf{2}}$ & 0.915737 & -0.049439 & 0.073581 & -0.027508 \\
\hline $\mathbf{C r}$ & 0.343731 & 0.110067 & -0.702187 & -0.073091 \\
\hline $\mathbf{M n O}$ & 0.053622 & 0.111364 & -0.095655 & 0.778606 \\
\hline $\mathbf{F e}_{2} \mathbf{O}_{3}(\mathbf{T})$ & 0.946322 & 0.00489 & 0.038389 & 0.135418 \\
\hline $\mathbf{Z n}$ & 0.12317 & 0.172467 & 0.251327 & 0.734501 \\
\hline $\mathbf{R b}$ & 0.704904 & 0.231607 & 0.000074 & 0.371147 \\
\hline $\mathbf{S r}$ & 0.324723 & 0.753607 & -0.027315 & 0.395016 \\
\hline $\mathbf{Y}$ & 0.825307 & 0.158985 & 0.021735 & -0.023666 \\
\hline $\mathbf{Z r}$ & 0.585845 & 0.513799 & -0.042001 & -0.153702 \\
\hline $\mathbf{N b}$ & 0.79021 & 0.077895 & -0.146456 & 0.17055 \\
\hline Expl.Var & 4.235177 & 1.85933 & 1.170934 & 1.520024 \\
\hline $\mathbf{P r p} . \mathbf{T o t l}$ & 0.352931 & 0.154944 & 0.097578 & 0.126669 \\
\hline
\end{tabular}


Table 2: Eigenvalues of the factor analysis corresponding to the first four factors. 